
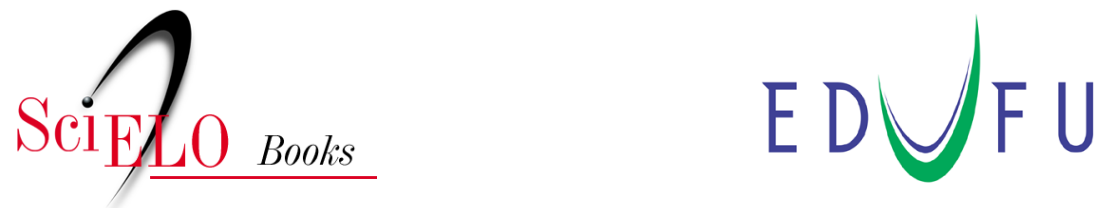

\title{
A educação escolar na obra-trajeto de Maurício Tragtenberg legitimação do poder versus autogestão pedagógica
}

Doris Accioly e Silva

\section{SciELO Books / SciELO Livros / SciELO Libros}

ACCIOLY E SILVA, D. A educação escolar na obra-trajeto de Maurício Tragtenberg: legitimação do poder versus autogestão pedagógica. In: BOTO, C., ed. Clássicos do pensamento pedagógico: olhares entrecruzados [online]. Uberlândia: EDUFU, 2019, pp. 293-317. História, Pensamento, Educação collection. Novas Investigações series, vol. 9. ISBN: 978-65-5824-027-3. Available from: http://books.scielo.org/id/fjnhs/pdf/boto9786558240273-14.pdf. https://doi.org/10.14393/edufu-978-857078-472-8.

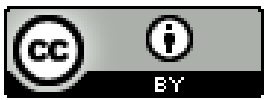

All the contents of this work, except where otherwise noted, is licensed under a Creative Commons Attribution 4.0 International license.

Todo o conteúdo deste trabalho, exceto quando houver ressalva, é publicado sob a licença Creative Commons Atribição 4.0.

Todo el contenido de esta obra, excepto donde se indique lo contrario, está 


\title{
A educação escolar na obra-trajeto de Maurício Tragtenberg: legitimação do poder versus autogestão pedagógica ${ }^{1}$
}

Doris Accioly e Silva

\author{
Para ser grande, sê inteiro \\ nada teu exagera ou exclui \\ sê todo em cada coisa \\ póe quanto és no minimo que fazes \\ assim em cada lago \\ a lua toda brilha \\ porque alta vive!
} Fernando Pessoa (1933)²

A face mais bela [de Maurício Tragtenberg] é a total ausência de preconceitos - um transitar tranqüilo entre os bens simbólicos de todas as classes sociais que gostaria de ver eliminadas para o surgimento de uma unica humanidade, fraternal, solidária e sem hierarquias.

Dulce C.A. Whitaker (2002) ${ }^{3}$

${ }^{1}$ Para Roseana Leite e Fernando Claudio Prestes Motta, in memoriam. Para a família de Maurício Tragtenberg, Dulce C. A. Whitaker, Jenny Aisenberg e Baldur Liesenberg.

${ }^{2}$ Fernando Pessoa. Odes de Ricardo Reis. Lisboa: Ática, 1946 (imp.1994). (Notas de João Gaspar Simões e Luiz de Montalvor.)

${ }^{3}$ Whitaker, Dulce C. A. Maurício Tragtenberg: uma vida para as ciências humanas. Educ. Soc., v.23, n.78, abr. 2002, p.299-302. 
Maurício Tragtenberg foi um dos exemplos raros de intelectual cuja obra-trajeto desenha uma polifonia, na qual pensamento e prática se entrelaçam e se completam. Neste artigo acompanhar-se-á essa unidade localizando suas conexões nas memórias de Maurício Tragtenberg e nos depoimentos sobre ele, incluindo minhas próprias lembranças de 26 anos de convívio com o autor. A obra-trajeto é alinhavada pela noção de "quadros sociais da memória", criada por Maurice Halbwachs (1957). De tais quadros surgem as dimensões coletivas contidas nas lembranças, pois a memória humana é fenômeno multilinear e profundamente vinculado às experiências sociais, extravasando os limites dos indivíduos e de sua circunscrita temporalidade.

Denomino depoimentos ressonantes os depoimentos pessoais que remetem à inseparabilidade memória-projeto, atributos humanos essenciais, e à reverberação de determinada experiência na vida dos sujeitos, transbordando os limites cronológicos (Accioly e Silva, 2005). Os depoimentos ressonantes transcendem as experiências subjetivas, puxando os fios do tecido social e histórico e recriando a atmosfera de uma época, seus conflitos sociais, culturais e políticos.

A memória como dimensão da prática social envolve seus múltiplos aspectos: históricos, sociológicos, políticos, filosóficos, antropológicos, psicanalíticos. É, também, reorganizada pelos deslocamentos espaciais ocorridos conforme as contingências e/ou determinações externas que agem sobre os indivíduos, as famílias, as classes sociais e mesmo as nações. A seletividade da memória decorre igualmente das situações presentes, das transformações e escolhas possíveis operadas no decurso dos trajetos pessoais:

Não há evocação sem uma inteligência do presente; um homem não sabe o que é se não for capaz de sair das determinações atuais. Acurada reflexão pode preceder e acompanhar a evocação. Uma lembrança é um diamante bruto que precisa ser lapidado pelo espírito. Sem o trabalho da reflexão e da localização, ela seria uma 
imagem fugidia. O sentimento também precisa acompanhá-la para que ela não seja uma repetição do estado antigo, mas uma reaparição. (Bosi, 1979, p. 39).

É o trabalho da memória que emerge das lembranças de/ sobre Tragtenberg, ou seja, a lembrança como relação social e como resistência cultural, política e pedagógica. Maurício Tragtenberg nasceu no Rio Grande do Sul em 1929, na região rural de Erebango/Erechim. Seus avós imigraram da Ucrânia graças a um projeto de colonização do governo rio-grandense no início do século XX. Fugiam dos pogroms, terror permanente no seio das comunidades judaicas daquela região. É ele quem conta:

eu nasci no interior do Rio Grande do Sul, cidade de Erechim, em uma zona de colonização judaica, de camponeses, de origem judaica, que se dirigiram pra lá, vindo dos progroms e das perseguições da Rússia Czarista na década de 10. Então eu cresci lá. Nasci em 04 de novembro de 1929, com a crise. Morava em Erechim, onde os meus avós desenvolviam uma agricultura familiar, em que a família era uma unidade produtiva, e o interessante é o fato de eles desenvolverem esse tipo de agricultura e não se dedicarem ao comércio, que é mais ou menos a ocupação especializada dentro do grupo judaico em geral. Isso teve implicações interessantes, no sentido que eles eram profundamente agricultores, quer dizer, eles eram muito ligados à terra enquanto propriedade deles, enquanto valor afetivo e profundamente religioso. Então, uma coisa que eu me lembro até hoje, desde menino, é que o meu avô levantava toda manhã e perguntava a mim se o Messias já chegou, e logicamente eu respondia que não...(Tragtenberg, 1998, p. 8)

Experiência instigante da infância foi o desfile dos integralistas assistido em Porto Alegre e que constituiu a primeira vivência do fenômeno chamado de massas para Tragtenberg. As lembranças da escola indicam o perfil do futuro autodidata que ingressaria na 
Universidade de São Paulo por notório saber, tendo apenas o quarto ano primário.

Conheci as primeiras letras em Erebango, depois Erexim, numa escola pública que funcionava num galpão. Entre arreios, cheiro de alfafa e um quadro negro, tive meu primeiro contato com o ler, escrever e contar. (Tragtenberg, 1998, p. 10).

Apesar das precárias condições econômicas, os camponeses de Erebango recebiam da Argentina exemplares do jornal libertário Golos Truda, que a federação dos trabalhadores russos de Buenos Aires lhes enviava. Os quadros sociais da memória permaneceram muito vivos em Tragtenberg:

Os camponeses de Erebango, ajudados pela imprensa libertária, aprimoraram o senso coletivo de vida e trabalho aprendendo uns com os outros. Todos eram alunos e professores e aprendiam ao mesmo tempo os segredos do cultivo da terra. À luz de vela, à noite, aprendiam e ensinavam português, espanhol, russo e esperanto. Liase em Erebango muitos autores anarquistas russos como Kropotkine, Bakunin, especialmente Tolstoi com seu anarquismo religioso anticlerical, que era o autor preferido. (Tragtenberg, 1998, p. 9).

Inúmeras associações de camponeses foram criadas já em 1918. As colônias agrícolas conseguiram a autossuficiência em alimentos, o aperfeiçoamento educacional e a prática dos princípios anarquistas no seu cotidiano. A leitura de clássicos da literatura russa, como Tolstoi, Pushkin eTchekov era constante, paralelamente à da imprensa libertária, como o diário Americanie Izvestia a Revista Volna. De Paris, a revista Dielo Trouda que, após 1930, seria impressa em Chicago. De Detroit, a partir de 1927, a revista Probuzdenie, em circulação até 1963. De São Paulo,os jornais A Plebe, AVoz do Trabalhador, Ação Direta e OLibertário, além de periódicos em castelhano, como Voluntad, Tierra y Libertad e 
La Protesta. Na biblioteca dos colonos, haviam ainda obras de Bakunin, Kropotkine, Malatesta, James Guillaume, Rudolf Rocker, Emma Goldaman e Nestor Makno, provenientes do Canadá e da Argentina.

É transparente, nas memórias de Tragtenberg, a fonte originária de sua autonomia intelectual e das práticas solidárias características de sua obra-trajeto. Com a mudança da família para Porto Alegre, "instalando-se no Bonfim, o gueto judeu tão bem retratado nas obras do escritor Moacyr Scliar" (Tragtenberg, 1998, p. 11) frequentou o

grupo Escolar Luciana de Abreu, ainda hoje no bairro Azenha. Estávamos em pleno Estado Novo, com fotos de Getúlio em todos os bares da cidade, como símbolo presidencial e cara de menino de primeira comunhão. Lembro-me que houve um dia sem aulas. Isso se deveu à visita que Plínio Salgado fez a Porto Alegre [...]. A condição de judeu numa sociedade nacional mais ampla leva você a uma politização precoce. Isso porque a visita de Plínio Salgado era sentida no bairro judeu como a visita de um anti-semita que prepararia futuros pogroms, iguais aos vividos na Rússia, daí o temor e os comentários terem se espalhado pelo bairro. (Tragtenberg, 1998, p. 11).

O ambiente político do início da época de Vargas bem como a presença de publicações do movimento libertário internacional, marcaram sua trajetória inicial.

Em São Paulo, onde chegou com a família após longa viagem de trem, morou no Bom Retiro. Frequentou uma escola judaica ortodoxa, o Thalmud Torá. Lá, estudava as matérias do ciclo primário e comentários do Velho Testamento. Aprendeu o ídiche e o hebraico.

O trabalho chegou cedo à vida de Tragtenberg aos 11 anos para auxiliar a família após o falecimento do pai:

iniciei minhas universidades, frequentando um bar na rua Ribeiro de Lima, que tinha duas características: comida barata e mesa sem toalhas. Lá acorriam trabalhadores de origem letã, lituana, russa, 
polonesa; muitos haviam inclusive participado da Revolução Russa, haviam topado pessoalmente com Lênin, Trotsky, Zinoviev ou Bukharin. Não eram “temas” de academia e sim expressões de relações sociais e políticas vividas. (Tragtenberg, 1998, p. 11).

Com a queda da ditadura Vargas e a ebulição política daquele momento, Tragtenberg entrou em contato com o PCB, cuja sede do comitê estadual era vizinha de sua casa:

Foi lá que na venda da esquina da rua Catumbi, encontrei um operário espanhol com o inevitável bigode que, olhando minha aparência mirrada - na época meu apelido social era Gandhi, tal a magreza "Oh! Rapaz, queres ficar forte? Entre para o PCB". Contribuía para a mesma tendência, um sapateiro espanhol meu vizinho, que entre um prego e outro na sola do sapato, discorria sobre reforma agrária, o que fora a Guerra Civil Espanhola e a importância do PCB. Não tive dúvidas, ingressei na "base", uma célula de bairro que funcionava no Belém, inicialmente pequena, composta de um pedreiro, um operário têxtil e uma dona-de-casa. (Tragtenberg, 1998, p. 12).

Tragtenberg já havia lido toda a obra política de Plínio Salgado, Gustavo Barroso e Miguel Reale, como também as de "nazistas nacionais", como A. Tenório de Albuquerque e Tasso da Silveira. Dentre as "universidades" de Tragtenberg, ele menciona os cursos oferecidos pelo Partido Socialista na sede da Praça da Sé, nos quais conheceu Antonio Candido, que ministrava um curso sobre História do Brasil, e Azis Simão, que falava sobre o sindicalismo e a burocracia. Lia Lênin, Trotsky, além de Stalin. Ao lado de suas outras "universidades", a amizade com a família Abramo abriu-lhe os horizontes da cultura italiana e da crítica do bolchevismo.

O PCB, em 1945, no $4^{\circ}$ Congresso, justificava o apoio do partido à burguesia industrial para "acabar com o latifúndio e os restos do feudalismo": 
Falava-se com sagrado temor que o Brasil estava num processo de "revolução democrático-burguesa” e que a tarefa do Partido, além de lutar por uma Constituinte com Getúlio, era apoiar Adhemar de Barros ao Governo do Estado. Era a época do Tratado de Yalta, onde os Estados Unidos deixaram Stalin avançar sobre o Leste e os PCs ocidentais, por sua vez, "compunham" com os partidos burgueses como o De Gaulle, na França, de De Gasperi, na Itália, de Getúlio, no Brasil, combatendo as greves e pregando a "união nacional". (Tragtenberg, 1998, p. 13).

Ao mesmo tempo, Tragtenberg frequentava as reuniões de trabalhadores de tendências anarquistas, trotskistas e socialistas, além de comunistas e integralistas, nas quais havia fecundos debates. Foi então que soube, "através do vidreiro Domingos Taveira, militante sindical, como fora esmagada durante a Revolução Russa a oposição operária fundada por Kollontai, pelo governo Lênin-Trotsky" (Tragtenberg, 1998,p. 13). Com ossocialistas, conheceu a crítica de Rosa Luxemburgo aos "descaminhos do bolchevismo", e com um senhor português que trabalhava como lixeiro na limpeza pública, soube do esmagamento de Nestor Makno e de seus camponeses, bem como dos marinheiros de Cronstadt pelo exército vermelho sob o comando de Trotsky. Foi expulso do $\mathrm{PCB}$, porque convivia com trotskystas e "outros inimigos da classe operária” (Tragtenberg, 1998, p. 14).

Tragtenberg frequentava, aos sábados à noite, as conferências do Centro de Cultura Social anarquista, onde conviveu com Edgar Leuenroth, Pedro Catallo, Anita Carrijo, Mário Ferreira dos Santos e Jaime Cubero. Após a expulsão do PCB, iniciou a leitura dos clássicos marxistas e de Max Weber. Travou amizade com o jornalista Hermínio Sachetta, trotskysta, influência fundamental em sua vida.

Tragtenberg havia trabalhado como office boy de um laboratório farmacêutico, e por volta de 1946-1947, prestara concurso para escriturário do departamento de águas e energia elétrica. $\mathrm{O}$ contato prático com o ritualismo burocrático, com a apatia do burocrata diante 
do trabalho e com as diferenças de status nas burocracias públicas por meio dos diplomas acreditativos das escolas, aguçou seu interesse pela burocracia como alienação e controle.

Em 1950, uniu uma visão crítica da burocracia no movimento operário à visão interna da burocracia como estrutura. Foi quando Antonio Candido, no saguão da Biblioteca Municipal, de São Paulo mencionou a Tragtenberg uma lei federal que lhe permitiria a apresentação de uma monografia à Faculdade de Filosofia, Letras e Ciências Humanas da USP, para prestar vestibular e cursar a universidade (Tragtenberg, 1998, p. 15). Em seis meses escreveu a monografia Planificação: desafio do século $X X^{4}$. Na apresentação desse livro, escreveu Antonio Candido:

Com honestidade e heterodoxia, longe de dogmas e preconceitos, o autor circula entre fatos históricos, sociais e econômicos com uma formosa liberdade, manifestando a cada instante uma equação pessoal que não se quer omitir e que atua como presença fecundante. (Tragtenberg, 2009, p. 9).

Graduou-se em História no final da década de 1950 e ingressou por concurso no magistério oficial do estado, indo lecionar na cidade de Iguape, de onde foi para o I. E. Monteiro Lobato, em Taubaté. De lá foi para Mogi das Cruzes e, então, para o Ginásio Estadual Candido de Souza, no bairro do Sumaré, em São Paulo, em 1963. Recordou Tragtenberg que seus alunos liam Anísio Teixeira para a discussão de problemas pedagógicos com seus professores. Foi sua aluna, na época, a Profa. Dra. Ediógenes Aragão, hoje livre-docente aposentada da Faculdade de Educação da Unicamp:

Conheci o professor Maurício Tragtenberg em 1962, quando ingressei no ginásio. As primeiras lembranças são as que ficam, porque ligadas às

${ }^{4}$ Reeditado pela Editora Unesp sob o título $O$ capitalismo no século $X X$, em 2009. 
nossas emoções e descobertas. Foi ele que me iniciou pelos caminhos e descaminhos da História e particularmente da História do Brasil, em 1962/1963, no Ginásio Estadual Prof. José Candido de Souza, na Rua Diana, no Bairro do Sumaré [...]. Preocupado e engajado com os oprimidos, pobres, excluídos, Maurício Tragtenberg dava uma atenção especial para os estudantes que trabalhavam, pois ele mesmo sabia o que era conciliar trabalho diurno com estudo noturno. Era um intelectual interdisciplinar, ensinava a ver as relações entre todas as questões [...]. Suas aulas eram livres, não controlava a presença, assistia aula quem queria, o importante era participar; não usava livros didáticos, as aulas teóricas se iniciavam com uma exposição do tema, depois enfatizava as idéias mais importantes do autor e fazia um esquema geral para que pudéssemos estudar em casa. O livro Formação do Brasil Contemporâneo de Caio Prado Jr. era nossa referência e também para preparar os seminários, através dos quais éramos avaliados. Simultaneamente indicava também obras literárias, pois para ele História e Literatura se completavam; no meu caso as leituras indicadas seguramente estavam vinculadas à minha origem de classe, operária, nordestina, parda, hoje o politicamente correto seria dizer "afro-brasileira", filha de operário da construção civil e de uma lavadeira. Maurício Tragtenberg me indicava a leitura de Lima Barreto, Machado de Assis, Aluísio de Azevedo. Estimulava os estudantes a freqüentar as Bibliotecas Públicas, raras na época. Tínhamos encontro marcado aos sábados pelas manhãs para manusear, folhear livros na Biblioteca Municipal Mario de Andrade. Casualmente nos encontrávamos no bonde com destino à Praça Ramos de Azevedo, que parava ao lado do Teatro Municipal. Depois Maurício nos levava para fazer a inscrição para leitor da Biblioteca Circulante, onde retirávamos livros para o trabalho semanal. Depois de um lanche na Cafeteria Paulista percorríamos alguns sebos do centro. Aprendíamos História do Brasil com a Coleção Brasiliana, que reúne o que há de precioso na historiografia sobre Brasil. A indicação foi Fernão Cardim - Tratados da Terra e Gente do Brasil. Aliás me recordo que ele estava 
sempre atento aos nossos problemas e conflitos, indicando livros que nos ajudavam a refletir sobre nós mesmos, nossa realidade. Mesmo após não ser mais nosso professor continuou nos orientando em nossas leituras. (Aragão, Ediógenes apud Accioly e Silva, 2005, p. 116-119).

$\mathrm{Na}$ fala da Profa. Dra. Lucia Bruno, da Feusp, pode-se encontrar outro depoimento ressonante de grande importância para esclarecer a singularidade do professor Maurício Tragtenberg:

Maurício foi meu professor, em 1974, na PUC. Ele dava aula de política e era um professor bem diferenciado, não dava aquelas aulas convencionais, ele discutia muito com a gente a Revolução Russa, a Revolução Alemã e ele falava dessas revoluções de uma forma muito voltada para o que tinha ocorrido na prática, como é que as pessoas, aqueles grupos sociais todos, as várias tendências, como atuaram nesse período, colocando sempre a participação de soldados, trabalhadores, camponeses, etc. Então ele deu uma dimensão para a gente que nós não tínhamos, do que foi a participação popular na Revolução Russa. Não era a Revolução Russa feita pelo partido e grandes lideranças, o que a gente já conhecia; era a história da Revolução Russa através da história dos movimentos sociais naquele período. Ele trazia autores de que ninguém tinha ouvido falar, ficava todo mundo curioso, os poucos alunos que assistiam, porque ele não fazia prova e não fazia chamada, eram poucos os alunos que ficavam em sala de aula. Mas os poucos que ficavam, ficavam até o final e depois fizeram mestrado com ele; sempre mantiveram contato, enfim, acabaram desenvolvendo trabalhos paralelos com ele; você vê que ali se estabeleceu uma ligação forte, intelectual, pessoal. E foi então o primeiro professor que abriu todo um mundo pra gente, pelo menos para mim, de autores novos, que no Brasil sequer eram editados. Por exemplo, Rosa Luxemburgo não era discutida no Brasil, muito menos na Universidade. Bernstein, Kautsky, tudo isso nós vimos, estudamos todos aqueles autores da II Internacional, toda a polêmica da II Internacional. Depois, a Revolução 
Alemã, Otto Ruhle, Hermann Gorter, que eram os esquerdistas alemães que a esquerda oficial não referia porque tinham polemizado com Lênin. E depois o Maurício organizou uma coletânea, Marxismo Heterodoxo; ${ }^{5}$ lá tem o Makhaiski, russo. [...] O primeiro intelectual a fazer uma crítica de esquerda a essa esquerda e com autores de grande expressão [...]. Ele criticava a burocracia e nunca foi um burocrata, nunca cobrou presença de aluno, nunca ficou dando prova pra dar notinha, essa coisa toda. $\mathrm{E}$ as pessoas ficavam porque sabiam que estavam aprendendo, ali com ele. Não só conteúdos importantes, mas uma forma de olhar para a realidade, não é? Ali tinha toda uma metodologia de estudo, de análise da realidade social e quem pôde perceber não faltava por nada.

Ele sempre enfatizou muito essa questão da prática social, muito mais do que os discursos, as posturas oficiais, além dos anarquistas, que ele trouxe para o meio acadêmico, que ninguém ensinava, não é? E autores de todo tipo: Bakunin, Malatesta, Kropotkin, Rudolf Rocker, Makhno. Por outro lado, ele foi também o professor que ensinou a gente a ler os clássicos - Weber, Marx - com o mesmo respeito, quer dizer, dar o devido valor a um autor independentemente de concordar ou não com ele, o que é muito difícil [...] poucos têm a liberdade que ele tem, de pensar, de questionar tudo o que lê. Essa é a maior virtude do Maurício como professor. Ele não tem discípulos, nunca quis ter, sempre teve horror a isso, sempre fez piada das igrejinhas, pois um homem que nos empurra para ser autônomos é impossível ter discípulos.

E o pensamento dele sempre foi muito dinâmico, ele também mudava de idéia, revia, aí, é difícil ter discípulos, porque quando os discípulos assimilavam o que ele falou há um tempo, ele já mudou, ele já faz a crítica àquilo, já avançou, já relacionou outros dados, outras situações e mudou, é uma outra interpretação, distinta. É isso que faz de Maurício um pensador vivo [...]. Era um dos poucos intelectuais nos anos $70 \mathrm{e}$ 80 que realmente tinha uma participação nos movimentos sociais. Ele ia, você se lembra disso, em reuniões de grupos pequenos de oposição,

${ }^{5}$ Reeditado pela Unesp em 2011. 
de fábricas; nenhum intelectual estava preocupado com aquilo, porque aquilo não se parecia com a grande política. (Bruno, Lúcia apud Accioly e Silva, 2005, p. 107-113).

O empenho de Tragtenberg em conhecer a história e a cultura brasileiras em seus complexos meandros foi permanente. Um dos cursos de pós-graduação que ministrou na PUC de São Paulo, nos anos 1990, intitulava-se O Pensamento Politico Brasileiro e abarcava autores conservadores desde o período do Império. Iniciava as aulas com a seguinte pergunta: "Por que ler os conservadores? Porque são muito atuais". E discutia o livro de Raymundo Faoro, Existe um pensamento politico brasileiro? Era sua preocupação compreender a recorrência do conservadorismo brasileiro e das práticas e noções de conciliação (Tragtenberg, 1996). Em seus cursos, liam-se os grandes intérpretes do Brasil, como Faoro, Florestan Fernandes, Gilberto Freyre, Sérgio Buarque de Holanda, Caio Prado Jr., Paulo Prado, entre outros. Ensinava a interpretá-los sob a luz múltipla da crítica da ideologia, da filosofia, das ciências humanas. Inesquecível seu curso sobre o nazi-fascismo com a leitura de Behemoth, de Franz Neumann, análise erudita das singularidades históricas e jurídicas dos estados fascista e nazista, além de textos de Hitler, Mussolini, Rozenberg, Goebbels, confrontados com a própria história alemã e mundial da época. $\mathrm{O}$ curso sobre o pensamento político de Trotsky era realizado por meio da leitura de obras deste autor, interpretando as metamorfoses de seu pensamento e o seu significado político para a história das esquerdas. Muito fecundas eram suas aulas sobre o Pensamento Político Clássico (Maquiavel, Locke, Hobbes, Marx, Rousseau), sempre trazendo os autores para analisar questões do presente, como era possível acompanhar por meio de seus artigos irônicos, bem-humorados, em vários jornais, agora reunidos nos diversos volumes da Coleção Maurício Tragtenberg'.

${ }^{6}$ Por exemplo, "Maquiavel no ABC", no volume Autonomia operária, de 2011, e "Max Weber na Assembléia”, no volume A falência da politica, de 2009. 
Ele recorria também ao cinema para refletir com os alunos sobre vários temas, como a burocracia e a perda do sentido da vida nos filmes de Akira Kurosawa (Viver, Homem mau dorme bem); a repressão política no leste europeu como resultado da degradação dos processos revolucionários, nos filmes de Andrzej Wajda (Danton, Sem anestesia, $O$ homem de mármore, $O$ homem de ferro); a dimensão psicossocial do nazismo, as religiões como instrumentos de coerção e a incomunicabilidade humana como decorrência dos processos de alienação e internalização da repressão, no cinema de Ingmar Bergman (O ovo da serpente, Fanny e Alexander, Sonata de outono). Relacionados aos filmes, Mauricio Tragtenberg discutia textos de Kafka, Max Weber, Bakunin, Marx, Proudhon e tantos outros. Esse procedimento permitia aos alunos a formação de uma visão de mundo na qual a arte, a filosofia e as ciências se integravam, alargando e aprofundando múltiplos âmbitos da condição humana, vista sempre como inacabada.

Para a compreensão das concepções e práticas pedagógicas de Tragtenberg, é imprescindível ter em vista sua crítica permanente e radical às organizações burocráticas e às ideologias administrativas que invadiram o campo educacional. Desse modo, em Tragtenberg não é possível isolar a esfera escolar/educacional das demais esferas, nas quais dominam relações hierárquicas e de reprodução das relações de exploração e poder.

A naturalização de tais relações constitui o fenômeno da ideologia concebida por Maurício Tragtenberg como "verdade conflitual" (Ansart, 1978), ou seja, a expressão de forças sociais em luta e a projeção fantasmática de uma classe social ou segmentos de classe que pretendem sua própria eternização no exercício da dominação política e da exploração econômica. Segundo João Bernardo (1977, p. 201), "Quando digo que uma dada ideologia é errada, quero dizer que ela não exprime a minha prática. Mas por que, em vez de a exorcizar como errada, não referir antes à prática de quem a produziu?”. A obratrajeto de Maurício Tragtenberg é, uma teoria crítica das organizações 
como o Estado, a Escola e a Empresa, construída em contraponto às noções e práticas autogestionárias. Nessa construção, é fundamental o modo de organização interno das instituições, a sua forma, para além de seu conteúdo ideológico. Para Tragtenberg, as instituições que reproduzem em seu cotidiano as hierarquias internas, separando os que planejam e os que executam, não só se submetem ao Estado capitalista como nele se integram.

Para outro grande crítico da burocracia, Fernando Cláudio Prestes Motta (1990, p. 19), não se pode opor, de modo simplista, a verdade científica e a ideologia, pois

as ciências constituem parte do modo de dominação burocráticomeritocrático que caracteriza nossas vidas. Seu esforço continuado é o de tentar fundir a racionalidade substantiva na racionalidade instrumental, justificando determinado tipo de ordenação social voltada para a produtividade e o lucro. (Motta, F. C. P., 1990, p. 19).

Pode-se afirmar que Fernando Cláudio Prestes Motta e Tragtenberg compartilham uma crítica das organizações que desmistifica o cientificismo no qual se amparam a meritocracia acadêmica e o intelectual burocraticamente legitimado pela academia. Uma teoria organizacional voltada à mudança do estabelecido

precisa antes de mais nada recusar as falsas automatizações do campo, que sob a capa da 'diferença específica' referem-se ao Estado e à escola sem referência à empresa, num mundo onde as instituições converteram-se, malgrado o desejo dos idealistas, em simples apêndice do aparelho econômico (Motta, 1990, p. 19).

Nas suas teses de doutorado (Burocracia e Ideologia) e de livredocência (Administração, Poder e Ideologia), defendidas respectivamente em 1972 e 1979, Tragtenberg funde o conceito de ideologia em Marx e o de burocracia em Max Weber, estudando as teorias da administração 
como transitórias e ambíguas (ideológicas), ainda que operacionais no nível técnico:

Como nascemos, vivemos e morremos em organizações formais, as teorias explicativas destassão de primordial importância, principalmente, quando pela intervenção do Estado na economia o próprio Estado aparece como organização. Daí qualquer análise da Teoria Administrativa deve partir da burocracia enquanto poder para atingir a burocracia na estrutura da empresa. (Tragtenberg, 1992, p. 16).

$\mathrm{Na}$ tese de livre-docência, Tragtenberg critica a reorganização do capitalismo internacional a partir da década de 1970, quando

o papel central das grandes corporações na condução da vida social a que hoje se dá o nome de Mercado; a separação entre propriedade e controle do processo econômico conferindo aos gestores tecnocratas um poder econômico e político inaudito; e as novas formas de exploração do trabalho, calcadas, cada vez mais no componente intelectual do trabalho, provocando uma mudança substantiva nas formas disciplinares do capitalismo. (Bruno, 2004).

Reiterando os eixos temáticos centrais de seus primeiros estudos, Tragtenberg (2004) realizou críticas agudas à escola capitalista, estatal ou privada, que permanecem profundamente atuais. Nos textos $A$ delinqüencia acadêmica, Universidade e hegemonia, e $O$ saber e o poder ele desvenda os compromissos de setores hegemônicos das universidades com os interesses políticos e econômicos do Estado e das empresas, materializados nos financiamentos de organismos internacionais e agências estatais de fomento à pesquisa em detrimento do pensamento crítico e criativo próprio das humanidades. A análise que Tragtenberg realiza não apenas da universidade, mas da escola em geral, põe em cheque seu lugar social e suas finalidades, perguntando a quem ela 
serve e de que modo se realiza esse servir. Dialogando com Bourdieu, Establet, Benjamin, Goffman, Lobrot, Ferrer, Foucault, Castoriadis, as reflexões de Tragtenberg movem-se com amplitude e radicalidade entre os polos da escola reprodutora das relações sociais e as noções e práticas da educação anarquista, da autogestão pedagógica, negadora da escola burocrática e heterogerida. Também para Fernando Cláudio Prestes Motta (1981, p. 132), em seu belo estudo sobre Proudhon e a autogestão,

nenhum órgão, mesmo nacional, deverá ser investido do poder de controlar as opiniões e de impor um pensamento comum: a espontaneidade da razão coletiva exige que as opiniões diversas possam ser exprimidas, confrontadas, desvendando os conflitos e os antagonismos objetivos. Não é de uma síntese acabada e destrutiva das antinomias que brotará o dinamismo social: é somente através de tensões e de equilíbrios móveis que poderá se desenvolver e se exprimir a espontaneidade social. Insistindo sobre a espontaneidade operária e a gestão autônoma, Proudhon anunciava a criação dos conselhos operários, o sindicalismo revolucionário e as tentativas atuais de autogestão.

Tragtenberg percebeu com clareza a inseparabilidade da autogestão pedagógica, da autogestão generalizada da sociedade e da autogestão de nós mesmos. Portanto, a autonomia e a solidariedade são dimensões da unidade biopsicossocial. Esse é um fio condutor para compreender a obra-trajeto aqui estudada.

Em 1963, Tragtenberg foi convidado pelo Prof. Wilson Cantoni para lecionar Cultura Brasileira na Faculdade de Filosofia, Ciências e Letras de São José do Rio Preto, primeiro Instituto Isolado de Ensino Superior do Estado de São Paulo, hoje campus da Unesp. Esta experiência reuniu um brilhante grupo de jovens professores recém-formados pela USP em torno de um projeto políticopedagógico que incluiu a participação paritária de alunos e professores 
em todas as decisões do Departamento de Pedagogia;; a alfabetização de trabalhadores rurais e urbanos pelo método Paulo Freire; uma intensa vida cultural no interior da Faculdade, com grupo de Teatro e Cineclube, afirmando o compromisso do ensino superior com as necessidades dos trabalhadores. Nesta perspectiva socializava-se o saber, visando a formação de professores com rigoroso conhecimento da realidade local e regional ao lado do cultivo da cultura clássica e universal. Desta experiência, entre 1957 e 1964, participaram professores brasileiros e estrangeiros (Casimiro dos Reis Filho, Norman Potter, Flávio Di Giorgi, José Aluysio dos Reis Andrade, Fernando de Carvalho, Arnold Von Buggenhagen, Michael Löwye Mauricio Tragtenberg entre outros), dispersados após a repressão da ditadura militar sobre a Faculdade, em abril de 1964. Atingido por dois Atos Institucionais, Tragtenberg foi internado no Instituto Aché por três meses com esgotamento nervoso ${ }^{7}$.

Pouco conhecida também foi a participação de Tragtenberg como professor no ensino superior privado em Ribeirão Preto, São Paulo, entre o início e o final dos anos 1970. Com ele, trabalharam intelectuais que formaram gerações de pesquisadores e professores no Brasil, como Bento Prado Jr., Octavio Ianni, Edgard de Assis Carvalho, Evaldo Amaro Vieira e Newton Belisário. Este último, chamado por Bento Prado Jr. de a "esquerda tragtenberguiana", não trilhou a vida acadêmica. Nessa ocasião, tendo sido sua aluna, pude conhecer e conviver com todos eles. Esse fato mudou minha vida e foi decisivo em minha escolha profissional. Durante o período mais sombrio da Ditadura Militar, Tragtenberg ministrava cursos sobre Marx, Weber e o movimento anarquista, sendo muitas vezes chamado para interrogatório na Polícia Federal da cidade, o que não o fazia desistir da crítica.

Em 1978, o primeiro número da revista Educação e Sociedade,

\footnotetext{
${ }^{7}$ Vide artigo de Lúcia Bruno e Doris Accioly e Silva, intitulado "Maurício Tragtenberg, a ousadia de conhecer", publicado na revista "Educadores Brasileiros" em abril de 2011.
} 
que ele ajudou a criar, publicou seu artigo sobre "Francisco Ferrer e a Pedagogia Libertária”, trazendo para a universidade brasileira um debate que ela havia omitido. No artigo sobre Ferrer, Tragtenberg fez uma análise histórica da Espanha desde a Reconquista aos Árabes, esclarecendo a especificidade espanhola na Europa, a articulação entre as classes sociais dominantes e destas com o Estado e a Igreja.É a partir das conexões delineadas por esse quadro que se pode compreender o papel revolucionário do anarquismo espanhol e das Escolas Modernas, fundadas por Francisco Ferrer, a quem Tragtenberg denominava "desertor da burguesia". A pedagogia de Ferrer é uma das primeiras recusas práticas e teóricas da pedagogia capitalista, privada ou estatal, desde os métodos, a relação professor-aluno à visão de mundo. Ferrer, na esteira de Paul Robin e Sebastien Faure, recusa as notas, a presença obrigatória, os prêmios e castigos, as hierarquias e o ensino religioso. Pratica a coeducação sexual das classes sociais, um ensino vinculado à observação da natureza e à arte, concebendo o conhecimento com base na ciência, e esta como libertação de preconceitos e ruptura do pacto saber-poder. As Escolas Modernas, assim, ameaçaram a ordem dominante. O assassinato político de Francisco Ferrer, em 1909, prova a dimensão dessa ameaça. Também no Brasil, as referidas Escolas Modernas, aqui fundadas pelos anarquistas, não foram poupadas pela repressão no início da República.

Outra característica importante do pensamento de Tragtenberg é a heterodoxia com que absorvia a multiplicidade de autores do campo marxista, anarquista, weberiano e dos clássicos da Literatura e das Ciências Sociais. Isso não significava relativismo ou ecletismo, hoje novamente em voga, mas a capacidade de extrair das leituras suas lições mais radicais e esclarecedoras para a compreensão de nossa sociedade. $\mathrm{Na}$ apresentação aos Textos escolbidos, de Kropotkin ${ }^{8}$, Tragtenberg recorda um aspecto pouco conhecido e muito atual das obras do referido autor.

${ }^{8}$ Presente no volume Teoria e ação libertárias, indicado nas referências. 
Em seu texto de memórias Em torno de uma vida, ele mostra o abismo entre as gerações e critica um sistema educacional fundado na disciplina, que leva à dissipação e à mentira; nos programas de cursos impostos, que anulam a originalidade, a iniciativa e a responsabilidade; e nas avaliações que criam o ódio, a competição e o ciúme. Kropotkin não se limita à crítica, propõe uma educação integral que promova o desenvolvimento harmônico do indivíduo, integrando no seu processo de conhecimento, as ciências naturais e as históricas. Uma educação fundada no desenvolvimento da dignidade e da independência pessoal, suprimida a obediência passiva e a servidão. Enfim, uma educação libertária, que consagra o sacrifício progressivo da autoridade em proveito da liberdade. (Tragtengberg, 2011, p.156).

Tragtenberg não só divulgou o anarquismo no plano intelectual como também agiu em consonância às concepções e práticas libertárias ao longo de sua vida. Foi um professor generoso e, ao mesmo tempo, um grande crítico da instituição escolar que tem sido incapaz de oferecer às novas gerações perspectivas e sentidos para além da mesquinha vinculação ao mercado, horizonte estreito para o qual a educação oficial, com raras exceções, concentra a sua mirada. Insistindo na formação integral dos seres humanos para a vida, a beleza e a sensibilidade - vividas na dimensão de uma razão libertada - e, na solidariedade internacionalista, Tragtenberg recusa também qualquer ortodoxia, mesmo autodenominada anarquista, e relembra a dimensão libertária da obra de Marx.

Ele nota, retomando Weber, que na escola burocrática o diploma substituiu o direito de nascença:

o sistema burocrático estrutura-se em nível de cargos, que por sua vez articulam-se na forma de "carreira", onde diploma acreditativo, tempo de serviço e conformidade às regras constituem pré-condições de ascensão. Seu modo de recrutamento e sistema de promoção são definidos por ela como sigilo, como mecanismo de comunicação 
intra-burocrático. Diluído nas diversas áreas de competência. [...] a estrutura burocrática do ensino no âmbito nacional desenvolve-se em três níveis: organização do pessoal; programas de trabalho; inspeções e exames. No que se refere ao pessoal, o burocrata da educação está separado dos meios de administração como o operário dos meios de produção, o oficial dos meios de guerra e o cientista dos meios de pesquisa. (Tragtenberg, 2004, p. 46-47).

Com Weber, pode-se compreender a universidade como instituição burocrática e, portanto, de dominação, que se legitima pela produção/transmissão de conhecimentos, exercendo, na verdade, um controle sobre o saber e substituindo sua produção ao criar um agente burocrático especializado na transmissão do mesmo. (Tragtenberg, 2004, p. 72, grifos do autor). Ao lado de Weber, Tragtenberg (2004) considerava muito importantes para a educação as obras de Selznick e Lobrot. O primeiro pelo conceito de cooptação, que é legitimada pelo sistema de concursos realizados conforme os critérios formais burocráticos, mas nos quais "o vencedor já está escolhido a priori” (Tragtenberg, 2004, p. 73). A universidade burocrática legitima o poder sobre os alunos pelo sistema de exames. Tragtenberg é enfático ao afirmar que "nenhuma reforma universitária digna desse nome tem concreção se não partir da abolição do sistema de exames, o batismo burocrático do saber" (Tragtenberg, 2004, p. 72). Essa pedagogia repressiva instaurou a troca de informações entre professores a respeito de alunos, a disciplinarização da mão de obra, um saber acrítico e formas de sentir e agir conforme a racionalidade exigida pelo poder, formando o futuro docente na burocracia acadêmica, ou executivo na burocracia empresarial, soldado na burocracia militar, ou clérigo na burocracia eclesiástica (Tragtenberg, 2004, p. 72-73). Nesse mundo sem amor e sem ódio, os meios se convertem em fins, confirmando o que dizia Sartre: os burocratas não podiam morrer porque jamais tinham vivido. Nas palavras de Fernando Cláudio Prestes Motta (1981, p. 76), 
A educação moderna convencional muito raramente se preocupa com o desenvolvimento da pessoa. Opta, normalmente e com a cumplicidade dos pais ansiosos, por filhos bem-sucedidos na "vida", pelo desenvolvimento funcional ou profissional, exacerbando a angústia do adolescente. As instituições educacionais, e de modo especial a universidade, nasceram como um espaço no qual o mestre formava seus discípulos através da convivência diária. Esse espaço tornou-se uma grande burocracia impessoal em que a convivência é meramente funcional. Busca-se formar boas engrenagens, no melhor dos casos, e não pessoas adultas, maduras individual e socialmente.

Entretanto, lembra Tragtenberg, a realidade é contraditória: gera a burocracia e seu antídoto, a autogestão de toda a vida social. Aqui surge a contribuição dos anarquistas e de autores como Lobrot:

Sem uma autogestão pelo menos em nascimento, sem uma responsabilização dos alunos por si próprios, sem uma destruição, pelo menos parcial, da burocracia pedagógica, não se pode esperar nenhuma formação verdadeira, portanto, nenhuma mudança na mentalidade dos indivíduos. Vê-se imediatamente qual a repercussão no plano social. A sociedade afunda-se em problemas e conflitos insolúveis. É preciso começar pela Escola. A sociedade de amanhã será pela Escola ou negar-se-á a si própria. (1966, p.84)

Toda a obra-trajeto de Maurício Tragtenberg constitui-se como unidade polifônica, na qual o todo está contido nas partes e vice-versa, como nos hologramas. Nessa unidade, a centralidade das práticas e concepções da autogestão constituem o seu movimento centrípeto e centrífugo (Accioly e Silva, 2005). Dissipando o persistente equívoco acerca do que é autogestão, sua especificidade frente aos "participacionismos", Tragtenberg (2011, p. 247) sublinha que a 
autogestão é o controle direto dos meios de produção pelos produtores auto-organizados em comitês de fábrica, comitês inter-fábricas, federação ou confederação de comitês. Significa a integração do econômico com o político através do controle operário da produção e da democracia direta, substituindo, assim, o tecnocrata administrador e o político profissional da democracia representativa.

A emancipação dos trabalhadores é obra dos próprios trabalhadores, já foi dito na I Internacional. Caberia, portanto, aos educadores e intelectuais identificados com um projeto libertário de transformação social desenvolver alternativas pedagógicas que comecem por romper a divisão interna ao próprio trabalho intelectual, cada vez mais fragmentado. Falar em autogestão pedagógica é colocá-la no horizonte da autogestão da totalidade social. Para compreender a dinâmica da obra-trajeto de Tragtenberg, é necessário lembrar que ele foi ao mesmo tempo crítico implacável de todas as burocracias, mas defendia a escola pública, laica e gratuita, porém gerida pelos trabalhadores, ou seja, realmente pública. Agnóstico, escreveu artigos memoráveis no jornal $O$ São Paulo da arquidiocese paulistana, quando à frente desta estava o Cardeal Evaristo Arns, adepto da teologia da libertação. Durante oito anos, escreveu no jornal Notícias Populares repudiado pela intelectualidade, mas lido pelos trabalhadores. Tragtenberg, como Bakunin, queria todo o conhecimento do século reapropriado pela classe operária, uma das condições de sua emancipação. Ao escrever sobre o pedagogo socialista Pistrak, explicava que este percebera a

necessidade de criar uma nova instituição escolar na sua estrutura e no seu espírito, suprimindo a contradição entre a necessidade de criar um novo tipo de homem e as formas da educação tradicional. Isso implicava uma profunda mudança na instituição escola, pois esta - Pistrak tinha plena consciência - transmite um conteúdo implícito significativo que devia ser questionado. Intuía Pistrak que o fundamental nas instituições decorre muito mais de uma prática não 
verbalizada do que do conjunto de enunciados solenes de que ela se faz porta voz. (Tragtenberg, 2011, p. 199).

São incontáveis os textos de Tragtenberg nos quais ele insiste na necessidade de auto-organização dos trabalhadores a partir de seus locais de trabalho e a reafirmação da capacidade do proletariado de gerir a vida social em todas as suas esferas. Às vésperas dos vinte anos de sua ausência, continuam vívidas sua lucidez, sua recusa a fazer concessões, sua capacidade de apreender o essencial para além das contingências e da banalidade cotidiana. Entendia ser fundamental que os professores colocassem seu "capital cultural" a serviço dos trabalhadores nos sindicatos, nas associações de bairro, nas comunidades de base. Só assim os intelectuais poderiam converterse em "intelectuais orgânicos" dos que são expropriados econômica, política e culturalmente, deixando de servir ao capital e sua reprodução ampliada (Tragtenberg, 2012). Vivemos tempos de apatia, cooptação, e heterogestão repetidos ao infinito nas avaliações institucionais de docentes, funcionários e alunos, inclusive internacionais, em nome da "qualidade". Esse procedimento, pautado pela produtividade do capital reforça a competição e a hiperespecialização em detrimento de concepções e práticas integradoras da condição humana e da própria vida. Nessa atmosfera a contribuição de Maurício Tragtenberg é indispensável.

\section{Referências}

ACCIOLY e SILVA, Doris. A obra-trajeto de Maurício Tragtenberg sob o prisma das Afinidades Eletivas. 2005. 223f. Tese (Doutorado em Sociologia) - Universidade Estadual Paulista, Araraquara, 2005.

ACCIOLY e SILVA, Doris. Repressão política, resistência e memória social: um estudo de caso. In: WITHAKER, Dulce. C. A.; VELÔSO, Thelma M. G. (Orgs.). Oralidade e subjetividade: os meandros infinitos da memória. Campina Grande, PB: Eduep, 2005.

ANSART, Pierre. Ideologias, conflitos e poder. Rio de Janeiro: Zahar, 1978. 
AUTOGESTIONS. Revue trimestrielle, n. 12-13, Toulose, França. 19821983.

BERNARDO, João. A autogestão da sociedade prepara-se na autogestão das lutas. Revista Piá Piou, São Paulo, n. 3, nov. 2005.

BERNARDO, João. Marx crítico de Marx. Porto: Afrontamento, 1977, v. 1.

BOSI, Ecléa. Memória e sociedade. São Paulo: T. A. Queiroz Ltda, 1979.

BRUNO, Lucia. (Orelha). In: TRAGTENBERG, Mauricio; Administração, poder e ideologia, São Paulo: Unesp, 2004.

BRUNO, Lucia. O que é autonomia operária. São Paulo: Brasiliense, 1985.

BRUNO, Lucia; ACCIOLY E SILVA, Doris. Maurício Tragtenberg: a ousadia de conhecer. Educação. Educadores brasileiros, São Paulo, p. 69-77, abr. 2011. Número especial.

GUILHERM, Alain; BOURDET, Yvon. Autogestão, uma mudança radical. Rio de Janeiro: Zahar, 1976.

HALBWACHS, M. Les Cadres Sociaux de La Mémoire. Presses Universitaires de France, 1957.

LOBROT, Michel. A pedagogia institucional: por uma pedagogia autogestionária. Lisboa: Iniciativas Editoriais, 1966.

MOTTA, Fernando C. Prestes. Burocracia e autogestão: a proposta de Proudhon. São Paulo: Brasiliense, 1981.

MOTTA, Fernando C. Prestes. O que é burocracia. São Paulo: Brasiliense, 1981.

MOTTA, Fernando C. Prestes. Organização e poder: empresa, estado e escola. São Paulo: Atlas, 1990.

REGO, Teresa Cristina (Org.). Educadores brasileiros: ideias e ações de nomes que marcaram a educação nacional. Curitiba: Ed. CRV, 2018.

TRAGTENBERG, M. Maquiavel no ABC. In: Autonomia operária. São Paulo: Unesp, 2011.

TRAGTENBERG, M. Max Weber na Assembleia. In: A falência da política. São Paulo: Unesp, 2009.

TRAGTENBERG, Mauricio (Org.). Kropotkin: textos escolhidos. Porto Alegre: L\&PM, 1987.

TRAGTENBERG, Mauricio. A Conciliação Hoje. In: MARRACH, Sonia A. Conciliação, neoliberalismo e educação. São Paulo: Fapesp/Unesp/Annablume, 1996. 
TRAgtenBERG, Mauricio. Administração, poder e ideologia. São Paulo: Unesp, 2004.

TRAGTENBERG, Mauricio. Burocracia e ideologia. São Paulo: Ática, 1992.

TRAGTENBERG, Mauricio. Educação ou desconversa? In: VIEIRA, Evaldo Amaro (Org.). Educaşão e burocracia. São Paulo: Ed. Unesp, 2012.

TRAGTENBERG, Mauricio. Memorial. Revista Educação e Sociedade, n. 65, Campinas, 1998.

TRAGTENBERG, Mauricio. Neoliberalismo e cultura universitária. In: MARRACH, Sonia A. Conciliação, neoliberalismo e educação. São Paulo: Fapesp/Unesp/Annablume, 1996.

TRAGTENBERG, Mauricio. O capitalismo no século XX. São Paulo: Unesp, 2009.

TRAGTENBERG, Mauricio. Pistrak: uma pedagogia socialista. In: VIEIRA, Evaldo Amaro (Org.). Teoria e Ação Libertárias. São Paulo: Ed. Unesp, 2011.

TRAGTENBERG, Mauricio. Prefácio. In: SANTILLÁN, Diego Abad. Organismo econômico da revolução: a autogestão na Revolução Espanhola. São Paulo, Brasiliense: 1980.

TRAGTENBERG, Mauricio. Uma prática de participação: as coletivizações na Espanha (1936/1939). In: VIEIRA, Evaldo Amaro (Org.). Teoria e Ação Libertárias. São Paulo: Ed. Unesp, 2011.

VALVERDE, Antonio J. R. (Org.). Maurício Tragtenberg: 10 anos de encantamento. Educ/Fapesp: São Paulo, 2011.

WHITAKER, Dulce C. A. Uma vida para as Ciências Humanas. Revista Educação e Sociedade, São Paulo, vol. 23, n. 78, p. 299-302, 2002. 